\title{
Unveiling the Values Inculcation Model among Mathematics Teachers in Developing Country: A Conceptual Approach
}

\author{
${ }^{1}$ Mukhtar Alhaji Liman, ${ }^{2}$ Mohd Burhan Ibrahim, ${ }^{3}$ Joharry Othman \\ ${ }^{I}$ Department of Education, University of Maiduguri, Borno state, Nigeria \\ ${ }^{2,3}$ Institute of Education, International Islamic University Malaysia
}

\begin{abstract}
The demand for valued-education particularly science education and mathematics education is increasing in light of the global technological advancement. However, research on the area of values associated with mathematics teaching and learning among mathematics teachers remains in its infancy in Nigeria. This study was conducted to unveil the effectiveness of the mathematical values inculcation model among secondary schools mathematics teachers in Nigeria. A sample of 509 mathematics teachers was drawn from the six states of the North Eastern Region of Nigeria. A self-constructed survey instrument was used to gather the data of the study. The independent variables of the study consist of ideological, attitudinal, sociological, computational and motivational mathematical values. Structural equation modeling technique and confirmatory factor analysis (CFA) were conducted. The findings of the study show that there is a significant covariant relationship among the latent constructs for values inculcation in mathematics teaching and learning. There is also adequate support of the values inculcation model among Nigerian mathematics teachers as the model fits the data.
\end{abstract}

Keywords: Unveiling, Values, Inculcation, Mathematics, Teachers

\section{Introduction}

The high level of mathematics examination failure in Nigerian secondary schools has been in an increasing arithmetical progression of positive terms and period. The advancement of emerging technology has also brought about unprecedented increased demand of mathematical knowledge. In recent times, secondary school mathematics teaching and learning has become a subject of discussion due to the widespread failure in the mathematics examination. Many students regarded mathematics as a difficult subject among all other school subjects. They also conceived that mathematics teaching and learning is for special people like gifted and talented individuals.

The direst situation to date was a result released by the two examinations body, namely the West African Examination Council (WAEC) and National Examination Council (NECO). The situation was quite empathetic in the sense that in the year (2009), (2010) and (2011) May/June Senior School Certificate Examination results released by WAEC, out of 1,373,009 in 2009 only about 356, 981 candidates, representing only 25.99\%, who took part in the examinations, had five credits including English Language and Mathematics. Virtually 75\% of the candidates failed! (http:// thewillnigeria.com/opinion/5994-exam-failure). While in 2010 out of 1,351, 557 only 337,071 candidates obtained credits in English language, Mathematics and at least three other subjects! (http://directory-nigeria.org/waec-releases-may-june-2010-2011results.html). Lastly in 2011, $1,540,250$ sat for the body's examination among which only $472,906(30.70 \%)$ got five credits including the English language and Mathematics! (http://timetjamb.lefora.com/2011/08/12/fact-about-waec-2011-result/).

This predicament is insignificant when compared to the statistics released by National Examination Council (NECO) regarding the (WAEC) results for 2009, which showed that only 126, 500 of the 1,260,765 candidates, just $10 \%$ of those who registered for the body's examination, passed five subjects, including English and Mathematics (http:// thewillnigeria.com/opinion/5994-exam-failure). It was the poorest result in the educational history of Nigeria (Lawson, 2000).

Doubtless there were many other factors that contributed to this unfortunate situation such as the lack of human and physical resources, insufficient numbers of qualified mathematics teachers, lack of teaching and learning materials/aids, classroom overcrowding, and teacher burn out to name a few. In spite of this, this paper attempts to explore and affirm values inculcation in mathematics teaching and learning, with view point that whether also its lacking contributes to this negative outlook of secondary schools' mathematics teaching and learning.

The question may be asked, what are these mathematical values? They are those values conveyed in the course of mathematics teaching and learning which have been conceptualized as the deep affective qualities which mathematics teachers promote and foster through formal school mathematics education (Bishop, \& Clarkson, 1998). According to White (1959) and Bishop and Clarkson (1998), mathematical values are associated with the nature of mathematical knowledge and are generated from the technique employed by the mathematicians of different cultures in exploring and developing mathematics as a discipline. Based on this, the 
study investigates three interrelated sources of values and extended values inculcation model which permeate mathematics classrooms, namely ideological, attitudinal, sociological, computational, and motivation mathematical values (Bishop, et al., 2010; Liman, Ibrahim \& Shittu, 2011). Based on such researches, this paper investigates what takes place regarding values inculcation in mathematics instruction within the confines of Nigerian secondary schools.

\section{Related Area Of Study}

The concept of values inculcation in mathematics teaching and learning may well be understood if it could be distinguished from related constructs such as "beliefs" and "attitudes". This relationship is evident in the second set of the 'taxonomy of educational objectives' conceptualised by Krathwohl, Bloom, and Masia (1964). Seah, (2008) is of the view that one way of considering values has been to perceive it as being a quality which is more significant than beliefs and attitudes. Hofstede (1997) regarded values as "feelings with an arrow to it: they have a positive and a negative side". Rescher's (1969) definition referred to a significant set of attitudes: "a value represents a slogan capable of providing rationalization of action by encapsulating a positive attitude toward a purportedly beneficial state of affairs" (p. 9). Hill (1991) also links values with a subset of beliefs with values being "those beliefs held by individuals to which they attach special priority or worth, and by which they tend to order their lives" (p. 4).

Another perspective evident in the previous studies regarded values as an internal and deep-seated position within the human psyche, which guides mankind's "persistent and consistent response to a family of related situations or objects" (Krathwohl et al, 1964, p. 166). In the language of Raths et al., (1987) affective constructs such as "attitudes" and "beliefs" were measures of values. While Rokeach's (1973) reference to values as enduring beliefs (p. 5) which concurred with Krathwohl et al., (1964) second set of 'taxonomy of educational objectives' on the affective domain. Kluckhohn (1962) made a point that "values differ from "beliefs" or "attitude" by the commitment to action in situations involving possible alternatives. Moreover, attached beliefs to the categories 'true/false', 'correct/incorrect', and values to 'good/bad' and this reference to values as indicative of one's notion of what is good or bad has also concurred with the assertion of (Nixon, 1995 $\&$ Tan, 1997).

Rokeach, (1973) introduced an additional dichotomy 'desirable/undesirable' to refer to values, and held the opinion that considering something as good or bad essentially represents the articulation of belief. In a similar direction, the judgement of truth and the correctness or goodness of any phenomenon is only possible and meaningful when it is situated in some context. A belief that 'mathematics is fun' concerns a true/false judgment which is made based on an object, i.e. the subject of mathematics and holding this belief does not mean believing that any other subject, or any other thing, is necessarily fun. Furthermore, the notion of what is desirable and not desirable does not necessarily require any specific target object. A person who values 'fun' will look for it and/or emphasise it in his/her mathematics classroom teaching and learning. It is a desirable quality in a somewhat personal and universal way. This is also evident in values listed in curriculum statements and in national value documents. Thus, although values may be operationalized in context, they are by themselves invariably context-free. Moreover, it has been reiterated that values are transcendental (across objects and situations).

Krathwohl et al., (1964) referred to the value system as being "broadest with respect to both the phenomena covered and to the range of behaviour which they comprise" (p. 185). Chin (2001) also supported the notion of values as being decontextualized beliefs which fits with the idea that each value develops from an interaction amongst several beliefs, reflect the internalisation continuum in the taxonomy of Krathwohl et al., (1964) and the valuing process of Raths et al., (1987).

Values development was seen as a process involving different affective objectives located along a multidimensional internalisation continuum. The most basic stage is 'receiving (attending)', when the individual's attention is drawn to a phenomenon. Successive stages are: 'responding', 'valuing', 'organisation', and 'characterisation (by value or value complex)' and this stages involve increasing levels of internalisation, greater levels of internal control over the ownership of affective objectives, and increasing complexities and abstraction of these variables (Krathwohl et al.,1964).

\section{Conceptual Model For The Study}

Prior to this study, several dimensions and conceptualizations of mathematical values have been used via a qualitative methodology. For instance, Bishop (1988) and (1998) and Clarkson and Bishop (1999) developed a conceptual frame-work for mathematical values inculcation. This study adopts and extends the three interrelated cluster model for values inculcation in mathematics teaching and learning. Figure: 1 shows the propose model for the study. 


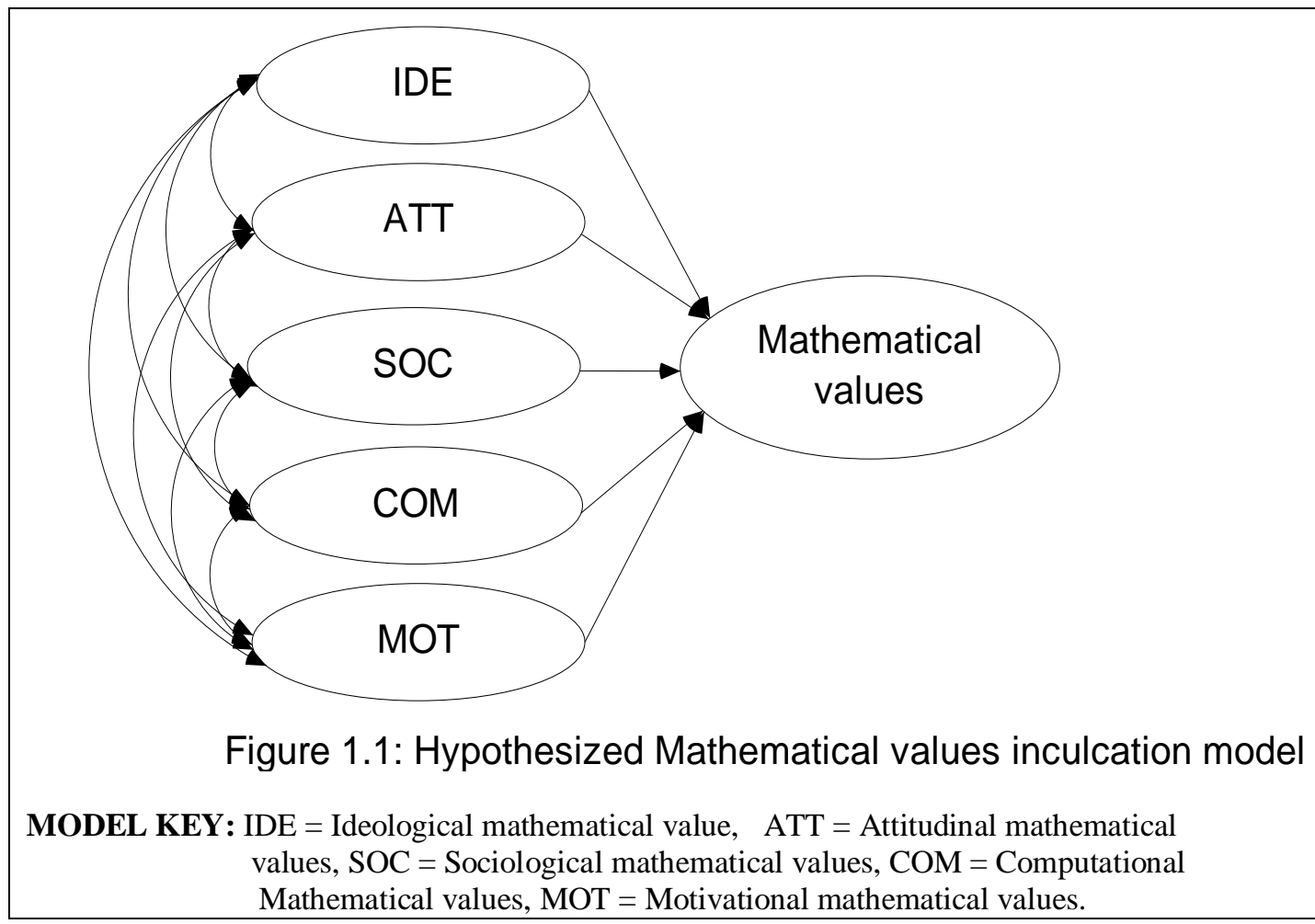

\section{Research Questions And Hypotheses}

This study intends to answer the following research questions and hypotheses based on the underlined conceptual frame-work in order to understand how values are inculcated in mathematical contents delivery.

\section{Research Questions}

Q1: Is there any significant covariance relationship between the listed constructs for values inculcation in mathematics teaching and learning?

(i) Ideological and Attitudinal mathematical values.

(ii) Attitudinal and Sociological mathematical values.

(iii) Sociological and Computational mathematical values.

(iv) Computational and Motivational mathematical values.

(v) Sociological and Motivational mathematical values.

(vi) Ideological and Sociological mathematical values.

(vii) Ideological and Computational mathematical values.

(iix) Ideological and Motivational mathematical values.

(ix) Attitudinal and Computational mathematical values.

(x) Attitudinal and Motivational mathematical values.

Q2: Does the model for values inculcation in mathematics teaching and learning fit the data?

\section{Research Hypotheses}

H1: There will be a significant covariance relationship between the latent constructs of values inculcation in mathematics teaching and learning.

$\mathrm{H} 2$ : The mathematical values inculcation model will fit the data.

\section{Population and Sample Size}

\section{Methodology}

The data for the study were collected through self-constructed survey instruments. The mathematical values inculcation survey questionnaires were administered to mathematics teachers teaching mathematics at various levels of secondary schools in the North Eastern Region of Nigeria. The region comprises of six states namely Adamawa, Bauchi, Borno, Gombe, Taraba and Yobe state. The study adopt stratify random sampling technique. Based on population of $\mathrm{N}=1145$ respondents and $95 \%$ confidence level, 3.5\% margin of error and online sample calculator, $\mathrm{n}=509$ were found to be used as the study's sample size (Krejcie \& Morgan, 1970). 
Unveiling the Values Inculcation Model Among Mathematics Teachers In Developing Country: A

Consequently, 599 questionnaires were distributed in order to run away from respondents' laxity of returning the questionnaire and to get a more reach data. Out of this number, 530 questionnaires which account for $88.5 \%$ were returned, 5 were totally not completed and 11 had one forms of mutilation or the other. As such, out of $530,16,(3.0 \%)$ were null and void and 514 which account for $96.9 \%$ questionnaires were keyed in into the SPSS Version 17.0. Thereafter, 5 responses to the questionnaires items, account for $.9 \%$ were found to be outliers and they were removed from the analysis. Table 1 and 2 depicts the detail procedure.

Table 1: Sampling Adequacy of Required Sample size

\begin{tabular}{cllllllll}
\hline $\begin{array}{c}\text { Population Size } \\
\text { (1) }\end{array}$ & \multicolumn{3}{c}{$\begin{array}{c}\text { Confidence }=\text { 95\% } \\
\text { Margin of Error (2) }\end{array}$} & & \multicolumn{3}{c}{$\begin{array}{c}\text { Confidence = 99\% } \\
\text { Margin of Error (3) }\end{array}$} \\
\hline & $5.0 \%$ & $3.5 \%$ & $2.5 \%$ & $1.0 \%$ & $5.0 \%$ & $3.5 \%$ & $2.5 \%$ & $1.0 \%$ \\
\hline 400 & 196 & 265 & 318 & 384 & 250 & 309 & 348 & 391 \\
500 & 217 & 306 & 377 & 475 & 285 & 365 & 421 & 485 \\
1,200 & 291 & 474 & 674 & 1067 & 427 & 636 & 827 & 1119 \\
1,500 & 306 & 515 & 759 & 1297 & 460 & 712 & 959 & 1376 \\
\hline
\end{tabular}

Source: The research advisors (2006).

Table 2: Sample Size for Mathematics Teachers

\begin{tabular}{lccccc}
\hline State & $\begin{array}{c}\text { Total no. } \\
\text { Distributed }\end{array}$ & $\begin{array}{c}\text { Total } \\
\text { Returned }\end{array}$ & $\begin{array}{c}\text { Percentage } \\
\text { Returned }\end{array}$ & $\begin{array}{c}\text { Total } \\
\text { Usable }\end{array}$ & $\begin{array}{c}\text { Percentage } \\
\text { Usable }\end{array}$ \\
\hline Adamawa & 103 & 92 & $89.3 \%$ & 88 & $95.7 \%$ \\
Bauchi & 96 & 84 & $87.5 \%$ & 81 & $96.4 \%$ \\
Borno & 108 & 97 & $89.8 \%$ & 93 & $95.9 \%$ \\
Gombe & 96 & 84 & $87.5 \%$ & 81 & $96.4 \%$ \\
Taraba & 93 & 82 & $88.2 \%$ & 78 & $95.1 \%$ \\
Yobe & 103 & 91 & $88.3 \%$ & 88 & $96.7 \%$ \\
Total & 599 & 530 & $88.5 \%$ & 509 & $96.0 \%$ \\
\hline
\end{tabular}

\section{Instrument Validity and Reliability}

Prior to the administration of the instrument, construct validity and the reliability of the instrument was ascertained. Factor analysis was conducted to validate the instrument of the study. Principal Component Analysis was used for extraction and Varimax used as the rotation method. The Kaiser-Meyer-Olkin measure of sampling adequacy (KMO) value of each construct was ascertained, the Barllet's Test of Sphericity value was significant $(\mathrm{p}=0.000)$, the Eigen value was greater than one and the percentage of variance explained of each factor was found to be greater than $40 \%$. Five factors were finally generated for the study. To ascertain the reliability of the instrument, Cronbach's Alpha was employed and the result showed values above 0.7, which indicated good internal consistency of the items. The table (3) below presents the 42 items used in the study, their loading and their cronbach alpha.

Table 3: Valid items and their Corresponding loadings and Alpha value

\begin{tabular}{|c|c|c|c|}
\hline Code & Ideological Mathematical Values (Measures) & Loadings & $\begin{array}{c}\alpha-\text { Value } \\
(.816)\end{array}$ \\
\hline IDE1 & $\begin{array}{l}\text { I emphasize on the value of precision in my mathematics } \\
\text { teaching. }\end{array}$ & .635 & \\
\hline IDE2 & $\begin{array}{l}\text { Logical reasoning is one of the values I encourage in my } \\
\text { mathematics teaching. }\end{array}$ & .631 & \\
\hline IDE3 & $\begin{array}{l}\text { In my mathematics teaching, I emphasize on the value of } \\
\text { working collaboratively. }\end{array}$ & .628 & \\
\hline IDE4 & $\begin{array}{l}\text { The teaching of equations enables me to convey the value of } \\
\text { equality in treatment to my students. }\end{array}$ & .687 & \\
\hline IDE5 & $\begin{array}{l}\text { I cultivate the value of truthfulness in my mathematics teaching } \\
\text { and learning. }\end{array}$ & .677 & \\
\hline IDE6 & $\begin{array}{l}\text { Perseverance is one value I encourage in my mathematics } \\
\text { teaching and learning. }\end{array}$ & .607 & \\
\hline
\end{tabular}


Unveiling the Values Inculcation Model Among Mathematics Teachers In Developing Country: A

\begin{tabular}{|c|c|c|c|}
\hline IDE7 & $\begin{array}{l}\text { In teaching mathematics, I encourage the value of competency in } \\
\text { problem solving of my students. }\end{array}$ & .643 & \\
\hline IDE9 & $\begin{array}{l}\text { The teaching of ratios and proportions enable me to convey the } \\
\text { value of honesty to my students. }\end{array}$ & .584 & \\
\hline IDE11 & $\begin{array}{l}\text { By asking applied questions, I encourage the value of critical } \\
\text { thinking of my students. }\end{array}$ & .636 & \\
\hline Code & Attitudinal Mathematical Values (Measures) & Loadings & $\begin{array}{c}\alpha-\text { Value } \\
(.797)\end{array}$ \\
\hline ATT13 & $\begin{array}{l}\text { Mathematical classroom discussions enable me to convey the } \\
\text { value of positive feeling to my students. }\end{array}$ & .613 & \\
\hline ATT14 & $\begin{array}{l}\text { Individual mathematical assignment presentations enable me to } \\
\text { cultivate the value of confidence in my students. }\end{array}$ & .661 & \\
\hline ATT15 & $\begin{array}{l}\text { Attending to my students' mathematical problems enable me to } \\
\text { convey the value of humbleness to my students. }\end{array}$ & .598 & \\
\hline ATT16 & $\begin{array}{l}\text { I act as a source of guidance to students in my mathematics } \\
\text { teaching. }\end{array}$ & .680 & \\
\hline ATT19 & $\begin{array}{l}\text { Punctuality is one of the values I emphasize in my mathematics } \\
\text { teaching and learning. }\end{array}$ & .689 & \\
\hline ATT21 & $\begin{array}{l}\text { In my teaching, I comfort those students who have difficulty in } \\
\text { mathematics learning. }\end{array}$ & .546 & \\
\hline ATT22 & $\begin{array}{l}\text { By allowing students to explore on mathematical problems, I } \\
\text { cultivate in them the value of creativity. }\end{array}$ & .666 & \\
\hline ATT23 & $\begin{array}{l}\text { Illustration of different methods of mathematical problem } \\
\text { solving, I cultivate the value of innovative tendency in my } \\
\text { students. }\end{array}$ & .625 & \\
\hline ATT24 & $\begin{array}{l}\text { I emphasize on the value of "practice make perfect" in my } \\
\text { mathematics teaching. }\end{array}$ & .693 & \\
\hline Code & Sociological Mathematical Values (Measures) & Loadings & $\begin{array}{c}\alpha-\text { Value } \\
(.753)\end{array}$ \\
\hline SOC26 & $\begin{array}{l}\text { Equal treatments of my students in mathematics teaching enable } \\
\text { me to convey the value of social justice. }\end{array}$ & .664 & \\
\hline SOC27 & $\begin{array}{l}\text { Mathematical knowledge sharing among students via project } \\
\text { based learning promotes the value of friendships. }\end{array}$ & .699 & \\
\hline SOC28 & $\begin{array}{l}\text { By allowing individual contributions to mathematics teaching } \\
\text { and learning of my students, I emphasize on the value of being } \\
\text { democratic. }\end{array}$ & .624 & \\
\hline SOC29 & $\begin{array}{l}\text { Appreciation of the beauty of nature is one of the values I } \\
\text { convey in my mathematics teaching of geometrical shapes, in } \\
\text { comparison with plants and architectural design. }\end{array}$ & .647 & \\
\hline SOC30 & $\begin{array}{l}\text { I organize mathematics career talk on values attached to } \\
\text { mathematics as a discipline. }\end{array}$ & .679 & \\
\hline SOC31 & $\begin{array}{l}\text { In teaching the concepts of probability, I emphasize on the value } \\
\text { of predictive tendencies of my students. }\end{array}$ & .702 & \\
\hline Code & Computational Mathematical Values (Measures) & Loadings & $\begin{array}{c}\alpha-\text { Value } \\
\text { (.835) }\end{array}$ \\
\hline COM32 & $\begin{array}{l}\text { I inculcate the value of curiosity in my students via mathematics } \\
\text { computer aided instruction (CAI). }\end{array}$ & .647 & \\
\hline COM33 & $\begin{array}{l}\text { Mathematics computer aided instruction (CAI) serve as a means } \\
\text { of inculcating the value of self management in my students. }\end{array}$ & .682 & \\
\hline COM34 & $\begin{array}{l}\text { Mathematics examples provided by means of computer cultivate } \\
\text { the value of interest in learning mathematics of my students. }\end{array}$ & .581 & \\
\hline COM35 & $\begin{array}{l}\text { Mathematics computer aided instruction (CAI) enables me to } \\
\text { emphasize on the value of immediate feedback to my students. }\end{array}$ & .608 & \\
\hline COM36 & $\begin{array}{l}\text { Mathematics computer aided instruction (CAI) enables me to } \\
\text { inculcate the value of self organization in my students. }\end{array}$ & .658 & \\
\hline COM38 & $\begin{array}{l}\text { Mathematics computer aided instruction (CAI) enables me } \\
\text { cultivate the value of social interaction in my students. }\end{array}$ & .661 & \\
\hline COM39 & Presentations of mathematics instruction via computers enable & .624 & \\
\hline
\end{tabular}


Unveiling the Values Inculcation Model Among Mathematics Teachers In Developing Country: A

me to convey the value of accuracy in my students.

COM40 Mathematics instruction via computer enables me to emphasize

on the value of preciseness in my students.

COM41 Mathematics interactive learning via computers cultivates the value of self dependency of my students.

COM43 Mathematics computer aided instruction (CAI) enables me to cultivate the value of self discovery learning of my students.

\begin{tabular}{|c|c|c|c|}
\hline Code & Motivational Mathematical Values (Measures) & Loadings & $\alpha-$ Value \\
\hline MOT44 & $\begin{array}{l}\text { I cultivate the value of hardworking in my mathematics students } \\
\text { by rewarding best performance. }\end{array}$ & .629 & \\
\hline MOT45 & $\begin{array}{l}\text { In my mathematics teaching, I motivate my students by telling } \\
\text { them benefits attributed to the learning mathematics. }\end{array}$ & .711 & \\
\hline MOT46 & $\begin{array}{l}\text { I motivate my mathematics students by relating mathematics } \\
\text { teaching to what they knew in their environment. }\end{array}$ & .721 & \\
\hline MOT47 & $\begin{array}{l}\text { I emphasize on the value of perseverance in my mathematics } \\
\text { teaching via problem solving of tough questions. }\end{array}$ & .692 & \\
\hline MOT48 & $\begin{array}{l}\text { I motivate my mathematics students by giving difficult } \\
\text { mathematical problems to solve. }\end{array}$ & .616 & \\
\hline MOT49 & $\begin{array}{l}\text { I emphasize on the value of pursuance of excellence in my } \\
\text { mathematics teaching by organizing mathematical competitions. }\end{array}$ & .630 & \\
\hline MOT50 & $\begin{array}{l}\text { I motivate my mathematics students by telling them the story of } \\
\text { past famous mathematicians. }\end{array}$ & .697 & \\
\hline MOT51 & $\begin{array}{l}\text { I motivate my mathematics students by seeing me as their role } \\
\text { model. }\end{array}$ & .704 & \\
\hline MOT52 & $\begin{array}{l}\text { I emphasize on the value of appreciation in my mathematics } \\
\text { teaching using positive reinforcements. }\end{array}$ & .630 & \\
\hline
\end{tabular}

\section{Confirmatory Factor Analysis (CFA)}

This study tested the proposed model fit to observed data using the structural equation modeling (SEM) technique. The proposed model consisted of five exogenous constructs, namely ideological, attitudinal, sociological, computational and motivational mathematical values inculcation constructs trying to predict values inculcation in mathematics teaching and learning. Research model testing and analyses were conducted through three general approaches. First, the proposed model analyses were conducted using covariances and the most widely used maximum-likelihood estimation method with AMOS 16.0 (Anderson and Gerbing 1992).

Furthermore, the measurement model development strategy for this study was followed using a model re-specification procedure which aims to identify the source of misfit and then generate a model that achieve better fit of data (Byrne, 2010). The study examined multiple statistics of model fit because a model may achieve good fit on a particular fit statistics but inadequate on others, (Bollen's, 1990). The selection of indices for this study was based on the recommendations of $\mathrm{Hu}$ and Bentler (1999) and Hair et al. (2010).

According to their recommendations, to achieve goodness-of-fit for the empirical data, both the measurement and structural model should meet the requirements of selected indices. Going by the suggestion of Hair et al., (2010), the first overall test of model fit selected was the chi-square test. A significant chi-square statistics indicates a poor model fit. As the chi-square test is extremely sensitive to sample size (Bentler 1990), the chi-square normalised by degrees of freedom $\left(\chi^{2} / \mathrm{df}\right)$ was also used. An acceptable ratio for $\chi^{2} / \mathrm{df}$ value should be less than 3.0 (Hair et al. 2010). According to Hair et al. (2010), researchers should report at least one incremental index and one absolute index, in addition to the chi-square value; at least one of the indices should be the badness-of-fit index. For the badness-of-fit index, RMSEA was chosen as it often provides consistent results across different estimation approaches (Sugawara and MacCallum 1993). Following this guideline, other than chi-square and normed $\chi^{2} / \mathrm{df}$ value, model fit for the present study was examined using multiple indices which include Goodness-of-Fit Index (GFI), Comparative Fit Index (CFI), Tucker-Lewis Index (TLI), Standardized Root Mean Square Residual(SRMR) and a badness-of-fit index, Root Mean Square Error of Approximation (RMSEA), (Hu and Bentler, 1999).

Following common practice, acceptable model fit is indicated by a value greater than .90 for GFI, CFI, TLI, IFI and a value of less than 0.08 for RMSEA. However, a cut-off value close to .95 for TLI, CFI; and a cutoff value close to .06 for RMSEA are needed to support that there is a relatively good fit between the hypothesised model and the observed data (Hu and Bentler 1999). Much in the same way as many other SEM researches, the more stringent criteria proposed by $\mathrm{Hu}$ and Bentler (1999) for approximate fit statistics were 
Unveiling the Values Inculcation Model Among Mathematics Teachers In Developing Country: A

adopted in the present study. Table 4 presents the summary of the recommended benchmark for the model fit indices adopted in the present study.

Table 4: Recommended Benchmark for Model Fit Statistics

\begin{tabular}{cc}
\hline Fit Index & Recommended Value \\
\hline$\frac{\text { Absolute Fit Measures }}{\chi^{2}}$ & The lower, the better \\
$\chi^{2 / d f}$ & $\leq 3.0$ \\
GFI & $\geq 0.90$ \\
RMSEA & $\leq 0.06$ or 0.08 \\
Incremental Fit Measure & $\geq 0.95$ or 0.90 \\
TLI & $\geq 0.95$ or 0.90 \\
IFI & $\geq 0.95$ or 0.90 \\
\hline
\end{tabular}

Source: Hooper, et al., (2008).

Researchers have reached a consensus that "validity is the most important concept in measurement" as such for this study to test the validity of measurement used, other than exploratory factor analyses which have been discussed in the earlier proceeding of this study confirmatory factor analysis (CFA) was employed to assess, develop, and modify the proposed conceptual model for values inculcation in mathematics teaching and learning. Anderson and Gerbing (1982, p. 453) claim that "good measurement of the latent variables is a prerequisite to the analysis of the causal relations among the latent variables". Hence, the present study adopts the two-step approach proposed by Anderson and Gerbing (1982). This approach is strongly preferred because structural analyses are often unreliable if the measurement model is of low reliability and validity (Hair et al. 2010). Based on data collected from 509 mathematics teachers, the measurement model was first revised and confirmed using confirmatory factor analysis. All latent constructs and its reflective indicators were depicted in a measurement model in which all latent constructs were allowed to correlate with each other. The confirmatory factor analysis (CFA) for instrument validation is represented by the measurement model in figure 1 where ovals represent latent variables and rectangles represent manifest (measured) variables.

The structural equation measurement model for values inculcation in mathematics teaching and learning in (figure:1) shows that the model needs to be revised in order to accomplished the objectives of this study guiding by the stated research questions and hypotheses of the study. Based on the model fit to the data, only the Normed chiq-Square and RMSEA has clinched to the cut-off point of $\geq 3.00$ for the normed chiqsquare and $\geq 0.06$ or $\geq 0.08$ for the RMSEA. The remaining fit statistics in the model have not met-off the stated thresholds of 0.9 and above (Hu and Bentler, 1999).

The researcher decided to revise the model by looking at the path measurement loading to the model in order to find items with offending loadings for the purpose of improving the model goodness-of-fit to the data. Interestingly all the loadings of the path measurement model constructs were above 0.5 as set out by the researcher but nevertheless the model needs to be improved for its goodness-of-fit to the data. Moreover, the covariance relationship among the latent constructs was statistically significant, that is to say there is significant relationship among the latent constructs for values inculcation model. Figure 2 gives the revised model. 


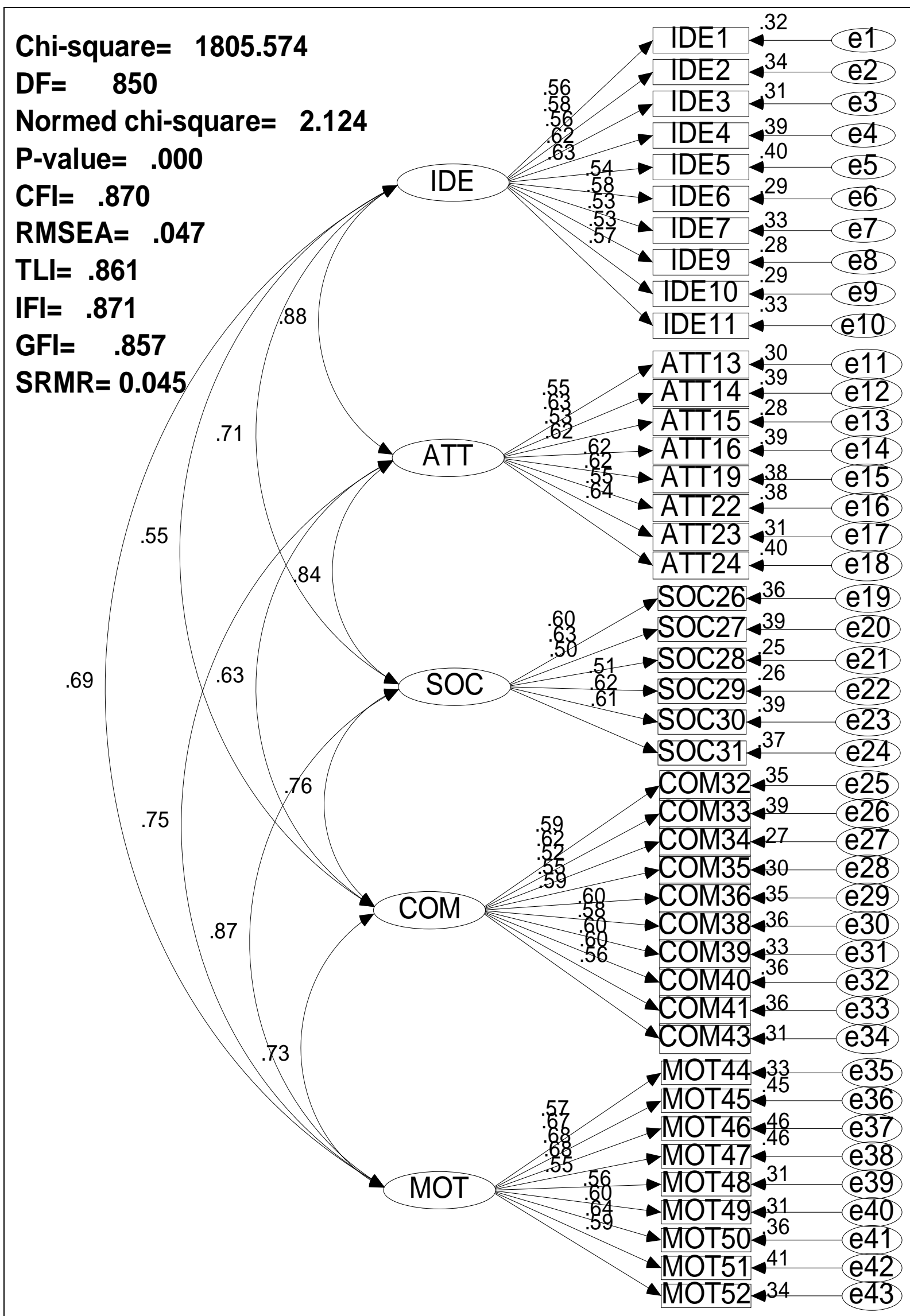

Figure1: Mathematical values inculcation model. 


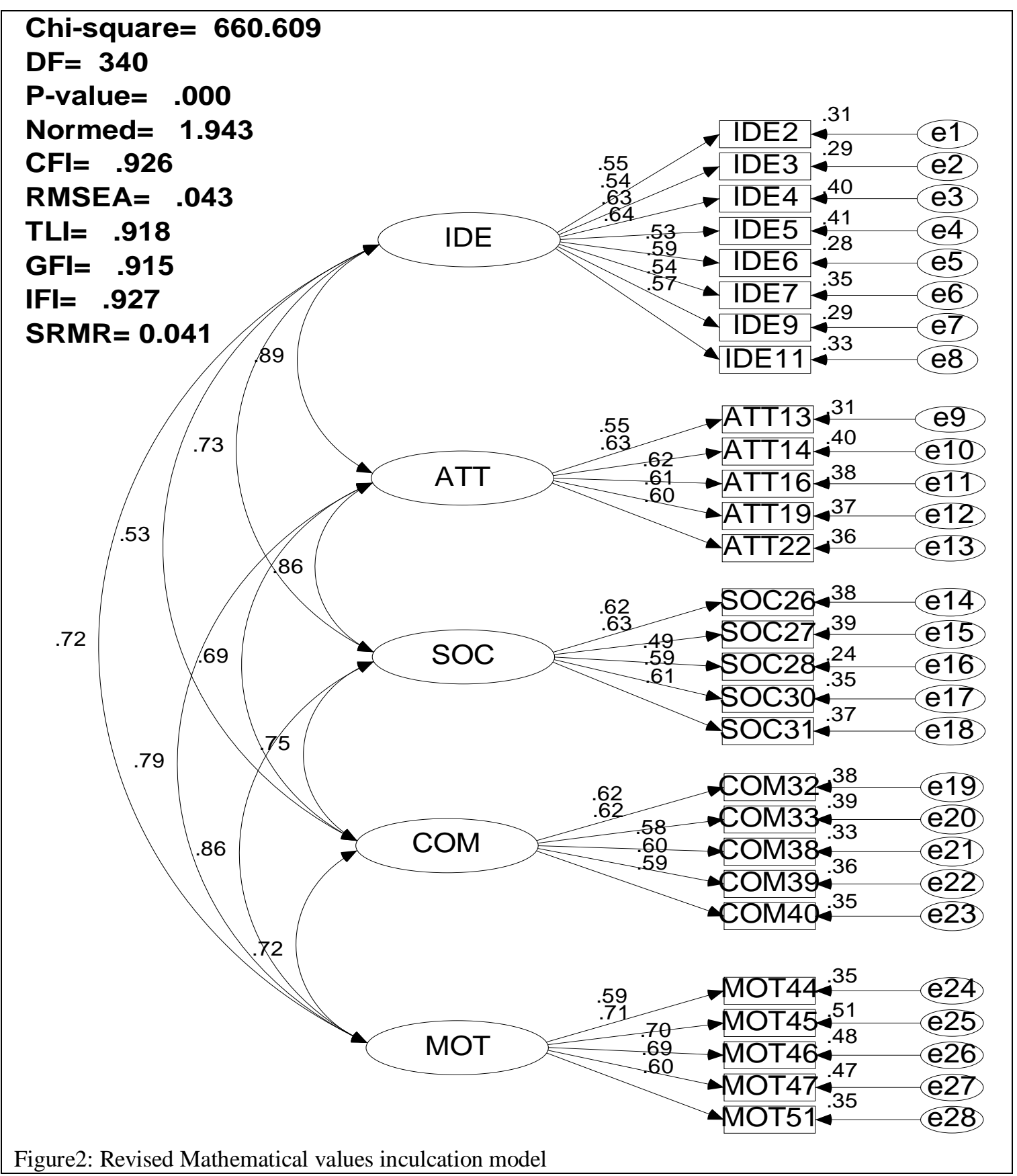

After a series of confirmatory factor analysis (CFA) inspection and cross-examination of the mathematical values inculcation model only 28 items were selected out of the 43 items, other offending items with square multiple correlations (SMC) less than 0.3 were deleted. The researcher thereafter assessed the hypothesized model (figure 2) so as to determine the extent to which the model fit the sampled data. The model was examined by evaluating the following fit statistics: the Chi-square, the Normed chi-square, the Comparative fit index (CFI), the Root Mean Square Error of Approximation (RMSEA), Goodness of fit index (GFI), Incremental Fit Index (IFI), Tucker-Lewis Coefficient Index (TLI) and standardized root mean square residual (SRMR).

The result of the fit statistics supports the proposed model for values inculcation in mathematics teaching and learning. This was because, the model adequacy as a whole indicated a good model fit with non significant chi-square statistics; $x^{2}(d f=340, N=509)=660.609, \mathrm{x}^{2} / \mathrm{df}=1.943, \mathrm{p}=.000, \mathrm{CFI}=0.926, \mathrm{RMSEA}=$ $0.043, \mathrm{GFI}=0.915, \mathrm{IFI}=0.927, \mathrm{TLI}=0.918, \mathrm{RMR}=0.113$ and $\mathrm{SRMR}=0.0406$. The relative chi-square where the chi-square fit divided by the degree of freedom $(\mathrm{CMIN} / d f)$ was estimated to be 1.943 the result fell below the threshold point of 3.000 (Kline, 2011). (Figure 2) and (Table 5) show the goodness-of-fit of the hypothesized model for values inculcation in mathematics teaching and learning. 
Unveiling the Values Inculcation Model Among Mathematics Teachers In Developing Country: A

Table 5: Goodness-of-fit and selected diagnostic measures for factorial validation of five factor structure of the mathematical values inculcation model

(Amos graphic version 16.0).

\begin{tabular}{lc}
\hline \multicolumn{1}{c}{ Fit indices } & Threshold \\
\hline$\chi^{2}$ for the Hypothesized Model (degree of freedom) & $660.6,(d f=340)$ \\
Normed Chi-square for Hypothesized Model (995.9/485) & 1.943 \\
Comparative Fit Index (CFI) & 0.926 \\
Root Mean square Error of Approximation (RMSEA) & 0.043 \\
Goodness of Fit Index (GFI), & 0.915 \\
Tucker-Lewis Coefficient Index (TLI) & 0.918 \\
Incremental Fit Index (IFI) & 0.927 \\
Standardized Root Mean Square Residual (SRMR) & 0.041 \\
\hline
\end{tabular}

Technically, when the proper assumptions are met, the Chi-square statistics can be used to test the null hypothesis that the model fits the data. However, in practice, the Chi-square statistics is very sensitive to external factors such as the sample size and multivariate normality, and will often result in a large value. For instance if the sample is large, it leads to the rejection of an otherwise reasonably well-fitting model. For this reason numerous researchers have recommended that the Chi-square statistics be used as a goodness-of-fit index with smaller chi-square relative to the degree of freedom $(d f)$ as indicative of a better model fit (Diamantopoulos \& Siguaw, 2000; James, Mulaik \& Brett, 1982; Joreskog \& Sorbom, 1993).

In considering the other goodness-of-fit statistics presented in Table 5 shown that the hypothesized model has goodness-of-fit values greater than 0.90 on the comparative fit index (CFI $=0.926)$, Goodness of fit index (GFI= 0.915), Incremental Fit Index (IFI= 0.927), Tucker-Lewis Coefficient Index (TLI= 0.918), respectively. All the aforementioned fit indexes clinched to the threshold of an acceptable model fit (Hooper,et al., 2008; Tabachnik \& Fidell, 2007; Bentler, 1999; Bentler \& Bonett ,1980).

Furthermore, according to Diamantopoulos and Siguaw (2000) "values of RMSEA less than 0.05 are indicative of good fit, between 0.05 and under 0.08 of reasonable fit, between 0.08 and 0.10 of mediocre fit and greater than 0.10 of poor fit" (p. 85). Root mean square residual $(\mathrm{RMR}=0.113)$ and standardized root mean square residual $(\mathrm{SRMR}=0.041)$ are also within the good fit statistic value, for a smaller value indicating a fitting model for (RMR) and less than 0.08 is indicative of good model fit (Hu \& Bentler, 1999).

Additionally, according to Hooper et al., (2008) a Normed Chi-square ratio in the range of 2:1 to 3:1 is generally considered indicative of a good fit of the data to the model. Therefore, to curve it all the hypothesized model in the present study has a ratio under 2:1 and that is an indication of a good fit of the data to the model. Based on these additional criteria for goodness-of-fit, the present model has (RMSEA $=0.043)$ less than 0.05 which indicated a good fitting model (Table 5).

Table 6: Covariance Matrix of Latent Factors

\begin{tabular}{lrrrrr}
\hline Factor Name & \multicolumn{1}{l}{ IDE } & ATT & SOC & COM & MOT \\
\hline IDE & 1.00 & & & & \\
ATT & .89 & 1.00 & & & \\
SOC & .73 & .86 & 1.00 & & \\
COM & .53 & .69 & .75 & 1.00 & 1.00 \\
MOT & .72 & .79 & .86 & .72 & \\
\hline PO
\end{tabular}

P> 0.05 Note: IDE=Ideological Mathematical values, ATT=Attitudinal Mathematical values, $\mathrm{SOC}=$

Sociological Mathematical values, $\mathbf{C O M}=$ Computational Mathematical values and $\mathbf{M O T}=$ Motivational Mathematical values.

In terms of the covariance relationship among the five latent constructs for values inculcation in mathematics teaching and learning, the analysis reveals that the inter-correlations between the constructs is statistically significant and acceptable with values ranging from .55 to .89 (Table 6). Therefore, in the light of goodness-of-fit summary information (Table 5) it is concluded that the factorial validation of mathematical values inculcation constructs among secondary school mathematics teachers is adequately confirmed as reasonably reliable and valid.

Table 6 summarizes the CFA results of factor loadings, indicator t-values (or convergent validity) and composite reliability estimate of the constructs of values inculcation in mathematics teaching and learning. Taken together, these results support the evidence concerning the extent to which the indicator in the newly 
Unveiling the Values Inculcation Model Among Mathematics Teachers In Developing Country: A

developed instrument, that is the mathematical values inculcation instrument represent reliable measures and appear to be measuring what they are intended to measure.

Table 7: Summary of Standardized Path Coefficients, Convergent validity and Composite Reliability

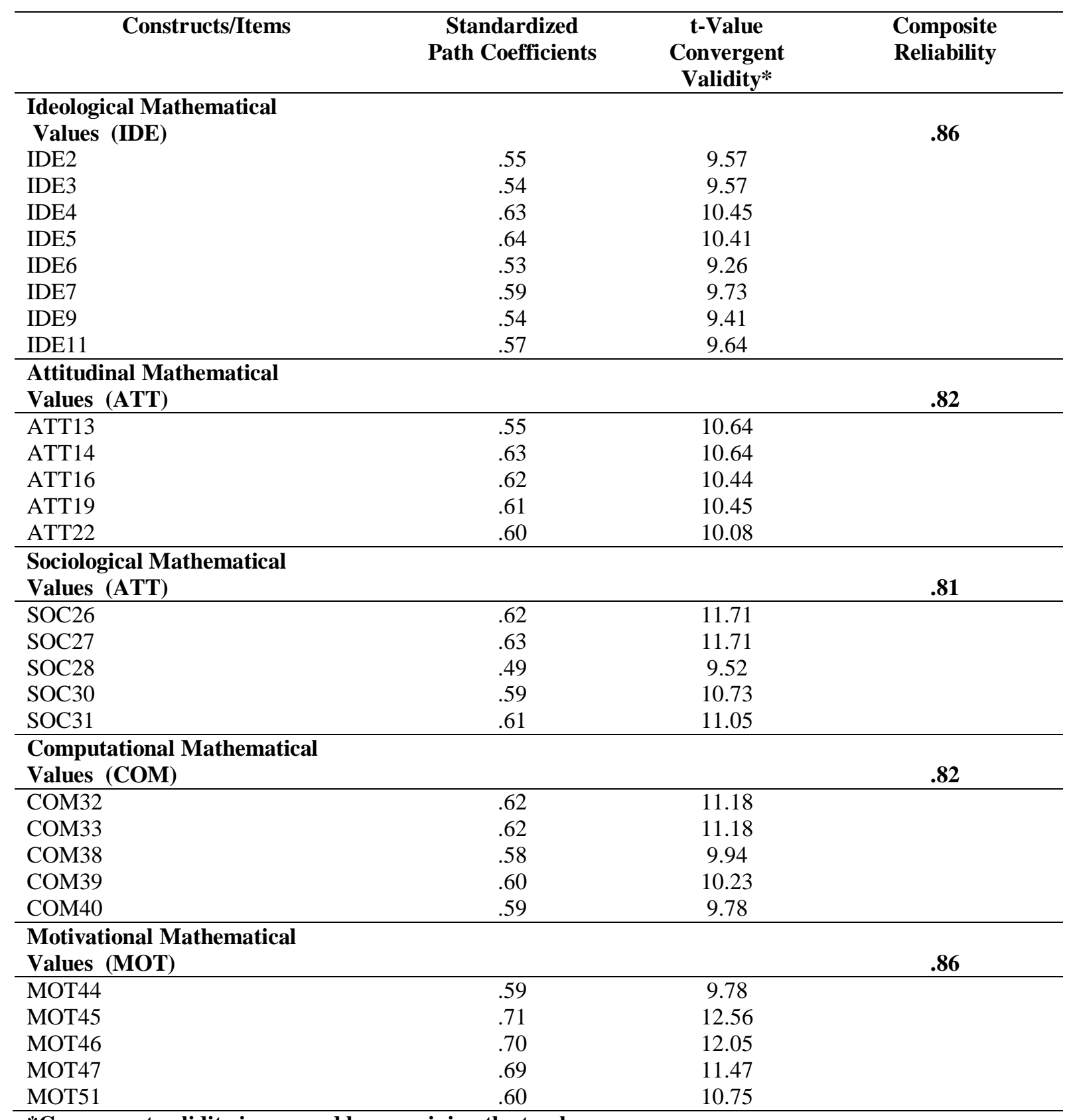

*Convergent validity is assessed by examining the $t$-values.

\section{Hypotheses Testing}

Confirmatory factor analysis (CFA) was used to analyze the hypotheses generated for the study. Prior to Confirmatory factor analysis (CFA) procedure, collinearity diagnostics were performed to ascertain that the data is free from multicollinearity. The result shows that the assumption of multicollearity has not been violated. A look at the VIF value shows that all the values were greater than 0.10 which is above the cut-off point for multicollinearity (Pallant, 2007). The data of the study has satisfied all the assumption for CFA analysis. The results of the tested hypotheses are hereby presented. 
Unveiling the Values Inculcation Model Among Mathematics Teachers In Developing Country: A

Table 8: Summary of the tested Hypotheses of the study

\begin{tabular}{|c|c|c|c|c|}
\hline & Hypothesis & Result & & Decision \\
\hline \multirow[t]{11}{*}{ H1 } & $\begin{array}{l}\text { There will be a significant covariance relationship between } \\
\text { the constructs of values inculcation in mathematics } \\
\text { teaching and learning. }\end{array}$ & Significant & & Supported \\
\hline & (i) Ideological and Attitudinal mathematical values & $(r=0.89)$, & $P>.5$ & Supported \\
\hline & (ii) Attitudinal and Sociological mathematical values. & $(r=0.86)$ & $P>.5$ & Supported \\
\hline & (iii) Sociological and Computational mathematical values. & $(r=0.75)$, & $P>.5$ & Supported \\
\hline & (iv) Computational and Motivational mathematical values. & $(r=0.72)$, & $P>.5$ & Supported \\
\hline & (v) Sociological and Motivational mathematical values. & $(r=0.86)$, & $P>.5$ & Supported \\
\hline & (vi) Ideological and Sociological mathematical values. & $(r=0.73)$, & $P>.5$ & Supported \\
\hline & (vii) Ideological and Computational mathematical values. & $(r=0.53)$, & $P>.5$ & Supported \\
\hline & (iix) Ideological and Motivational mathematical values. & $(r=0.72)$, & $P>.5$ & Supported \\
\hline & (ix) Attitudinal and Computational mathematical values. & $9 r=0.69)$ & $P>.5$ & Supported \\
\hline & (x) Attitudinal and Motivational mathematical values. & $(r=0.79)$, & $P>.5$ & Supported \\
\hline
\end{tabular}

\section{Discussions}

One of the cardinal objectives of this study has been to examine the covariance relationship among the latent constructs for the values inculcation measure. The findings showed that there were statistically significant covariance relationship between the five latent factors for values inculcation in mathematics teaching and learning (Table 6). The significance of these findings is to ascertain or confirm the degree of co-varying or relationship among the latent constructs. In terms of the strength of the relationship, this study revealed positive and close association between "ideological mathematical values" and "attitudinal mathematical values". Similar findings were found between "sociological mathematical values" and "motivational mathematical values." However, between "ideological mathematical values" and "computational mathematical values" followed by "attitudinal mathematical values" and "computational mathematical values", the association was also positive but moderate. It can be generally concluded that mathematical values inculcation constructs are correlated, that is to say they are linearly inter-dependent.

In realizing these relationship, Bishop, et al., (2010) asserted that values exist virtually through all levels of human relationships and endeavors. At the individual level, mathematics education as cultural induction has been well researched and it is now understood that values remain an integral part of any mathematics teaching and learning. In the classroom setting there are values inherent in the negotiation of meanings between mathematics teachers and students, and between mathematics students themselves. At the institutional everyone is engaged in value arguments about priorities in determining local curricula, schedules, teaching approaches and among other educational issues. On the larger perspective, that is the political scene or the societal level where the powerful institutions of any society has their respective values and priorities in terms of the mathematics curriculum and teachers preparation requirements, all of these challenged researches in the area of mathematics education and mathematical values inculcation in particular (Bishop et al., 2010).

Furthermore, at the cultural level, the sources of knowledge, beliefs, and language greatly influence our values in mathematics education and different cultures will influence values in different ways. This is because not all people share the culture (Bishop et al., n. d.). Finally, in terms of predicting tendency, this study found that all of the constructs contributed significantly toward the determination of the model fit. This concurred with the way in which the three constructs of mathematical values with six clusters model was conceptualized by (Bishop, 1988).

Secondly, the last objective of this study was to evaluate the model fit to the data and it was found that the hypothesized model for values inculcation in mathematics teaching and learning fit the data (Table5). Previous empirical study revealed that most of mathematics teachers teaching mathematics as a subject in the western cultural societies were either ignorant or had little knowledge about the values they were teaching in the classroom (Bishop, 1999). It was also asserted that little was known or has been written about the values that 
mathematics teachers thought they were imparting, or how successful they were in imparting these values (Bishop, et al., 2010).

Interestingly, the finding of this study differs from what was found in the western societies. This was because the finding of this study revealed that mathematics teachers in the North-Eastern Region of Nigeria were moderately aware of the values they taught in the classroom. This was substantiated by the data fitting to the hypothesized mathematical values inculcation model. Therefore, the researcher decided to conclude that mathematics teachers' were not ignorant and had minimum knowledge about the values they taught in their respective classes.

\section{Concluding Remark}

The findings of this study will have important implications to all stakeholders most especially mathematics educators, mathematics curriculum designers and educational administrators and policy makers on how to improve values inculcation in mathematical content delivery. Mathematics teachers should ensure and endeavor to be keen in inculcating the values that are imbedded in mathematical contents delivery. They should enable learners to see the beauty of learning mathematics rather than debunking the procedural aspect of mathematical contents delivery. Although values are interwoven in actualizing the ultimate objective of inculcating values in the teaching of mathematics, teachers should nevertheless emphasize values. Mathematics curriculum designers should be mindful in spelling out values conveyed in each mathematical text-module. This will enable mathematics teachers easy conveyance of values to learners. Educational administrators and policy makers should be more active in ensuring effective values conveyance in mathematics classroom teaching and learning with laudable policies such as train the trainers workshops, mathematical symposiums, and further inservice training of mathematics teachers.

\section{References}

[1] Anderson, J. C. \& Gerbing, D. W. (1992). Assumption and Comparative Strengths of the two-step approach: Comment on Fornell and Yi. Sociological Methods and Research, 20, 321-333.

[2] Basturk, R. (2005). The Effectiveness of Computer-Assisted Instruction in Teaching Introductory Statistics. Journal of Educational Technology \& Society, 8(2), 170-178.

[3] Beck, C. (1993). Learning to live the good life: values in adulthood. Toronto: OISE Press.

[4] Bentler, P. M. \& Bonnet, D. C. (1980). "Significance Tests and Goodness of Fit in the Analysis of Covariance Structures." Psychological Bulletin, 88 (3), 588-606.

[5] Bentler, P. M. (1990). Comparative Fit Indexes in structural equation model. Psychological Bulletin, 107, 238-246

[6] Bentler, P. M. (1999). Structural Equation Modeling with small samples: Test Statistics. Multivariate Behavioral Research, 34(2), 181-197

[7] Bishop, A. J. (1988). Mathematical Enculturation: A cultural perspective in Mathematics Education. Dordrecht, Holland: Kluwer.

[8] Bishop, A. J. (1999). Mathematics teaching and values education - an intersection in need of research. Zentralblatt fur Didaktik der Mathematik, 31(1), 1-4

[9] Bishop, A. J., \& Clarkson, P. (1998). What values do you think you are teaching when you teach mathematics? In J. Gough \& J. Mousley (Eds.), Mathematics: Exploring all angles (pp.30-38). Melbourne: Mathematical Association of Victoria.

[10] Bishop, A. J., Gunstone, D., Clarke, B., \& Corrigan, D. (2010). Values in mathematics and science education: Researchers' and teachers' views on the similarities and differences for the Learning of Mathematics, 26(1), 7-11.

[11] Bollen, K. A. (1990). "Overall Fit in Covariance Structure Models: Two Types of Sample Size Effects." Psychological Bulletin, 107 (2), 256-59.

[12] Byrne B. M. (2010). Structural Equation Modeling with AMOS: Basic concepts applications and programming. London, Routledge, Taylor and Francis Group.

[13] Diamantopoulos, A., \& Siguaw, J. A. (2000). Introducing LISREL. London: Sage Publications.

[14] Fennema, E. (1989). The Study of Affect and Mathematics: A Proposal Generic Model for Research. In McLeod, D.B./Adams, V. M. (Eds.) Affect and mathematical problem solving: A new perspective (pp.205-219). Springer, New York.

[15] Fraenkel, J. R. (1977). How to Teach about Values: An Analytical Approach, Englewood Cliffs, NJ: Prentice Hall.

[16] Hair J. F., Black W. C., Babin B. J., \& Anderson R. E. (2010). Multivariate Data Analysis. A global perspective. published by Pearson Education, Inc., Upper saddle River, New Jersey 07458.

[17] Halstead, J. M. (1996). Values and Values Education in Schools, In Halstead, J.M. \& Taylor, M.J. (Eds) Values in Education and Education in Values, London: The Falmer Press.

[18] Hill, B. V. (1991). Values Education in Australian Schools. Melbourne: Australian Council for Educational Research.

[19] Hooper, D., Coughlan, J., \& Mullen M. R. (2008). " Structural Equation Modelling: Guidelines for Determining Model Fit." Electronic Journal of Business Research Methods, 6 (1), 53-60. http://www..ejbrm.com.

[20] Hu, L.T., \& Bentler, P. M. (1999). "Cutoff Criteria for Fit Indexes in Covariance Structure Analysis: Conventional Criteria Versus New Alternatives." Journal of Research in Structural Equation Modeling, 6 (1), 1-55.

[21] Jöreskog, K. \& Sörbom, D. (1993). LISREL 8: Structural Equation Modeling with the SIMPLIS Command Language. Chicago, IL: Scientific Software International Inc.

[22] Kline, R. B. (2011). Principles and Practice of Structural Equation Modeling. London, The Guilford press.

[23] Kluckholm, C. (1962). Culture and Behaviour. New York: Macmillan.

[24] Krathwohl, D. R., Bloom, B. S., \& Masia, B. B. (1964). Taxonomy of educational objectives: The classification of educational goals. Handbook II: Affective domain. New York: David McKay.

[25] Lawson, B. (2000). A road Map for Education in Nigeria (part1) Nigerian Plus Citizen Journalism http:// nigeriaplus.com. 
[26] Le Métais, J., (1997). Values and aims underlying curriculum and assessment. International Review of Curriculum and Assessment Frameworks Paper 1 London: School Curriculum and Assessment Authority.

[27] Liman M. A., Ibrahim, M. B., \& Shittu A. T., (2011). Exploratory Factor Analysis: Validation of Mathematical Values Inculcation Model among Secondary Schools' Mathematics Teachers in North-Eastern Region Nigeria. Interdisciplinary Journal of Contemporary Research in Business, 3 (1), 64-72.

[28] Liman, M. A., Sahari, M. N., \& Shittu A. T. (2011). Confirmatory Factor Analysis: The Validation of Mathematical Values Inculcation Path Measurement Model Among Secondary Schools' Mathematics Teachers' in the North-Eastern Region, Nigeria. Inter-disciplinary Journal of Contemporary Research in Business, 2(11), 660-666.

[29] Nixon, J. (1995). Teaching as a profession of values. In J. Smyth (Ed.), Critical discourses on teacher development (pp. 215224). London: Cassell.

[30] Pallant, J. (2007). Survival Manual: A step by step guide to data Analysis using SPSS Windows.New York, Open University Press.

[31] Pritchard, A. J., \& Buckland, D. J. (1986). Leisure, values and biology teaching. Science and Technology Education, Document Series No. 22 Paris: UNESCO.

[32] Raths, L. E., Harmin, M., \& Simon, S. B. (1987). Selections from values and teaching. In P.F. Carbone (Ed.), Value theory and education (pp. 198-214). Malabar, USA; Krieger.

[33] Rokeach, M. (1973). The nature of human values. New York: The Free Press.

[34] Schlöglmann, W. (2001). Affect and cognition: Two poles of a learning process. Paper presented at the 3rd Nordic Conference on Mathematics Education. Kristianstad, Sweden.

[35] Schoenfeld, A., (1992). 'Learning to think mathematically: problem solving, meta cognition and sense making in mathematics', in D.A. Grows (ed.), Handbook of Research on Mathematics Teaching and Learning, MacMillan, New York, pp. 334-370.

[36] Seah, W.T. (1999). The portrayal and relative emphasis of mathematics and mathematics educational values in Victoria and Singapore lower secondary school textbooks: a preliminary study. Unpublished Master of Education thesis, Monash University, Melbourne, Australia.

[37] Stewart, J. S. (1987). Clarifying values clarification: A critique. In J. P.F. Carbone (Ed.), Value theory and education (pp. 215225). Malabar, FL: Robert E. Krieger.

[38] Straughan, R \& Wrigley, L. (Eds). (1980). Values and Evaluation in Education. London: Harper and Row.

[39] Tabachnick, B. G., \& Fidell, L. S. (2007). Using Multivariate Statistics (5th edition). New York: Allyn and Bacon.

[40] Tan, S. K. (1997). Moral values and science teaching: A Malaysian school curriculum initiative. Journal of Science and Education, 6, 555-572.

[41] White, L. A. (1959). The evolution of culture. New York: McGraw-Hill. 